\title{
Using Four-Tier Diagnostic Tests to Understand the Conceptions Held by Pre-Service Primary School Teachers about Sea Pollutant Migration
}

\author{
Wahyu SOPANDI \\ Universitas Pendidikan Indonesia, Bandung, INDONESIA
}

\author{
Rendi Restiana SUKARDI ${ }^{2}$ \\ Universitas Pendidikan Indonesia, Bandung, INDONESIA
}

\begin{abstract}
' Corresponding author: Dr päd, M.A.,. Universitas Pendidikan Indonesia, School of Post Graduate, Jl. Dr. Setiabudhi No. 229, Bandung, West Java, Indonesia. wsopandi [at] upi.edu ORCID: 0000-0002-1501-4064

2 .Pd.,. Universitas Pendidikan Indonesia, Campus of Cibiru, Elementary Education Study Program, Jl. Raya Cibiru KM 15, Bandung, West Java, Indonesia.. rendisukardi [at] upi.edu ORCID: 0000-0003-4121-7057
\end{abstract}

\section{Abstract}

The territory of Indonesia is dominated by vast oceans. Therefore, Indonesian citizens should be equipped with a deep understanding about sea currents and sea pollution. This study aims to identify the conceptions held by pre-service primary school teachers about both sea currents and sea pollutant migration. The study also aims to identify whether pre-service primary school teachers see a relationship occurring between those conceptions. The study involved 147 pre-service primary school teachers from one of Indonesia's teacher training institutions. Four-tier diagnostic tests were used to gather data about the conceptions of pre-service primary teachers. The data were interpreted and analyzed in a descriptive quantitative method. The results showed that pre-service primary school teachers' conceptions about sea currents and sea pollutant migration were mostly in the category of 'misconception' and 'have no conception'. The correlation test about the ability of pre-service primary school teachers to explain the concepts of sea currents and sea pollutant migration was also not significant. The results of this study indicate a need to improve the quality of teaching and learning for pre-service primary school teachers about convection by linking it to sea currents and sea pollutant migration.

\section{Keywords}

Four-Tier Diagnostic Test, Sea Pollutant Migration, Convection, Pre-Service Teacher Education, Sea Currents

To cite this article: Sopandi, W.; Sukardi, R., R. (2020). Using Four-Tier Diagnostic Tests to Understand the Conceptions Held by Pre-Service Primary School Teachers about Sea Pollutant Migration. Review of International Geographical Education (RIGEO), 10(2), 13-29. Retrieved from http://www.rigeo.org/voll0no2/Number2Spring/RIGEO-V10-N2-1.pdf. doi: 
Indonesia is the second-largest contributor of marine waste in the world after China and the amount of marine waste has been increasing over the last few years (Purba, 2017; Synthesis Report of the Ministry of Maritime Affairs, 2018). The quality of river water in Indonesia is also worsening due to the release of high pollutant substances into the sea and other waterways (Informasi Kinerja Pengelolaan Lingkungan Hidup Daerah Provinsi Jawa Timur, 2017; Martinus, Astono, \& Hendrawan, 2018). An investigation about river quality monitoring in Indonesia during 2013 also showed that $75.25 \%$ of river waters were heavily polluted and only $0.49 \%$ of river waters met the criteria of a clean water feasibility study (Kurniawan, 2013). Factory waste is not the only cause of pollution. Household waste is also a significant cause of pollution (European Commission's Directorate-General Environment, 2011; Informasi Kinerja Pengelolaan Lingkungan Hidup Daerah Provinsi Jawa Timur, 2017). Such a condition becomes a common concern because natural sustainability is a guarantee of the sustainability of living organisms and their ecosystems. These pollutants migrate into bodies of water and are spread far from where the pollutants originate. Therefore, it is fundamental for everyone, especially teachers, to understand about the concept of pollutant migration in bodies of water. A teacher is most responsible for ensuring that all citizens who have passed nine-years of compulsory education have adequate knowledge about pollutant migration. Furthermore, the teacher should correctly introduce changes in the environment, to map the conceptions of the environment, and create an integrated and sustainable environmental education program for students (Bolscho \& Havenschild, 2006; Kasimov, Malkhazova, \& Romanova, 2002; Surata \& Vipriyanti, 2018). The teacher must explain to students that pollutant migration into the sea occurs because of the presence of sea currents. Sea currents can be explained by using the concept of convection.

Convection occurs because of differences in water temperature, so water with higher temperature (lower density) moves from the surface of the water to the seabed. This movement is also followed by water with a lower temperature (higher density) moving up from the seabed to the surface. Both movements travel great distances, and together, create the global conveyor belt which plays a dominant role in determining the climate of many of the Earth's regions. Waters that move vertically or horizontally are called sea currents. The sea current is shown in Figure 1.

If the water contains pollutant particles, the movement of water particles can be followed by pollutant particles and cause pollutant migration. Based on this explanation, it can be concluded that a good understanding of convection (heat transfer accompanied by particle displacement) becomes a prerequisite concept for pre-service primary school teachers to understand about sea pollutant migration. The process of sea pollutant migration is shown in Figure 2. The concentration of pollutants decreases gradually in the garbage disposal site (Area A) whereas another site (Area B) increases. 
Sopandi, W.: Sukardi, R., R. (2020). Using Four-Tier Diagnostic Test to Understand the ...

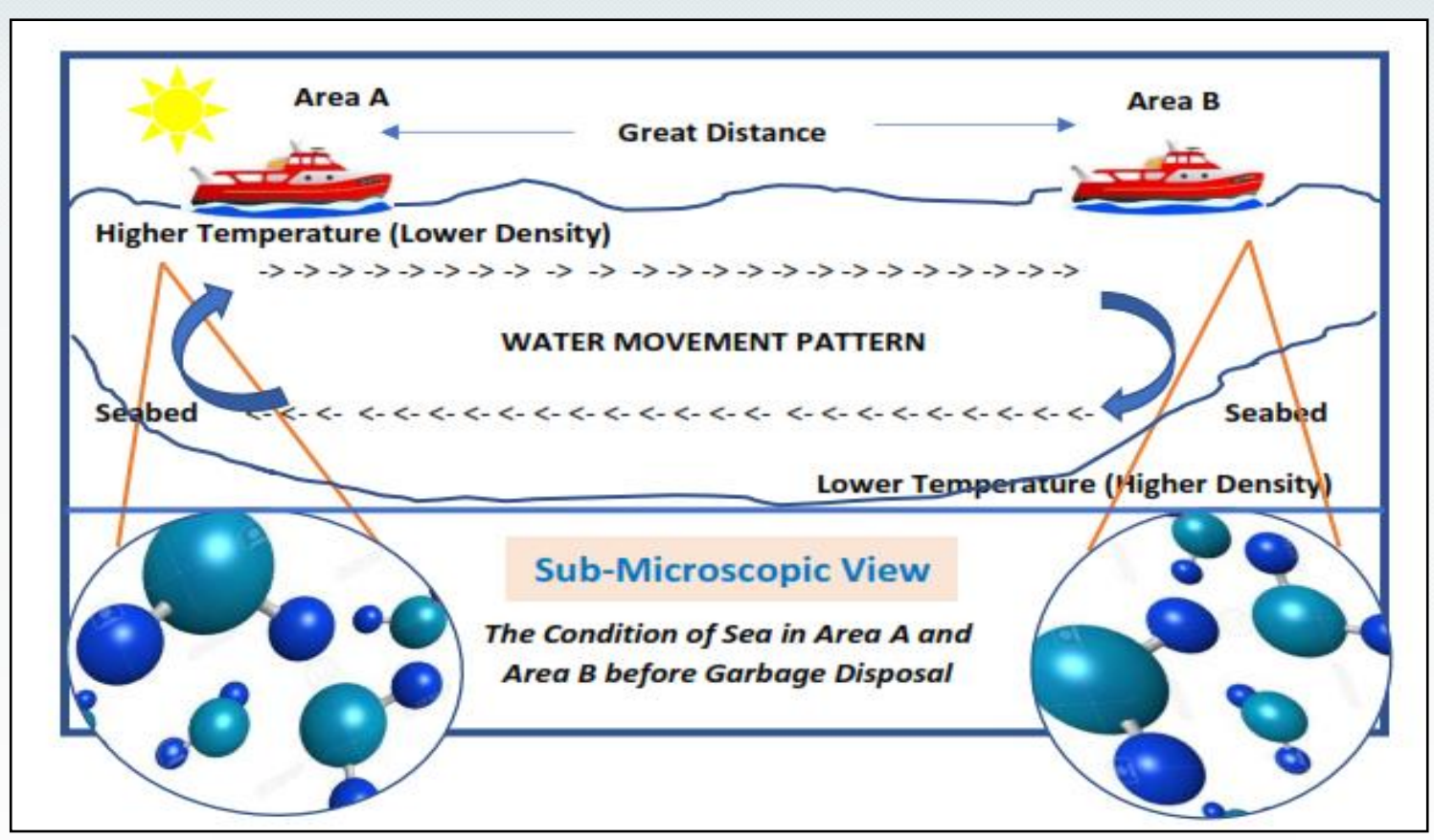

Figure 1. How sea currents move water

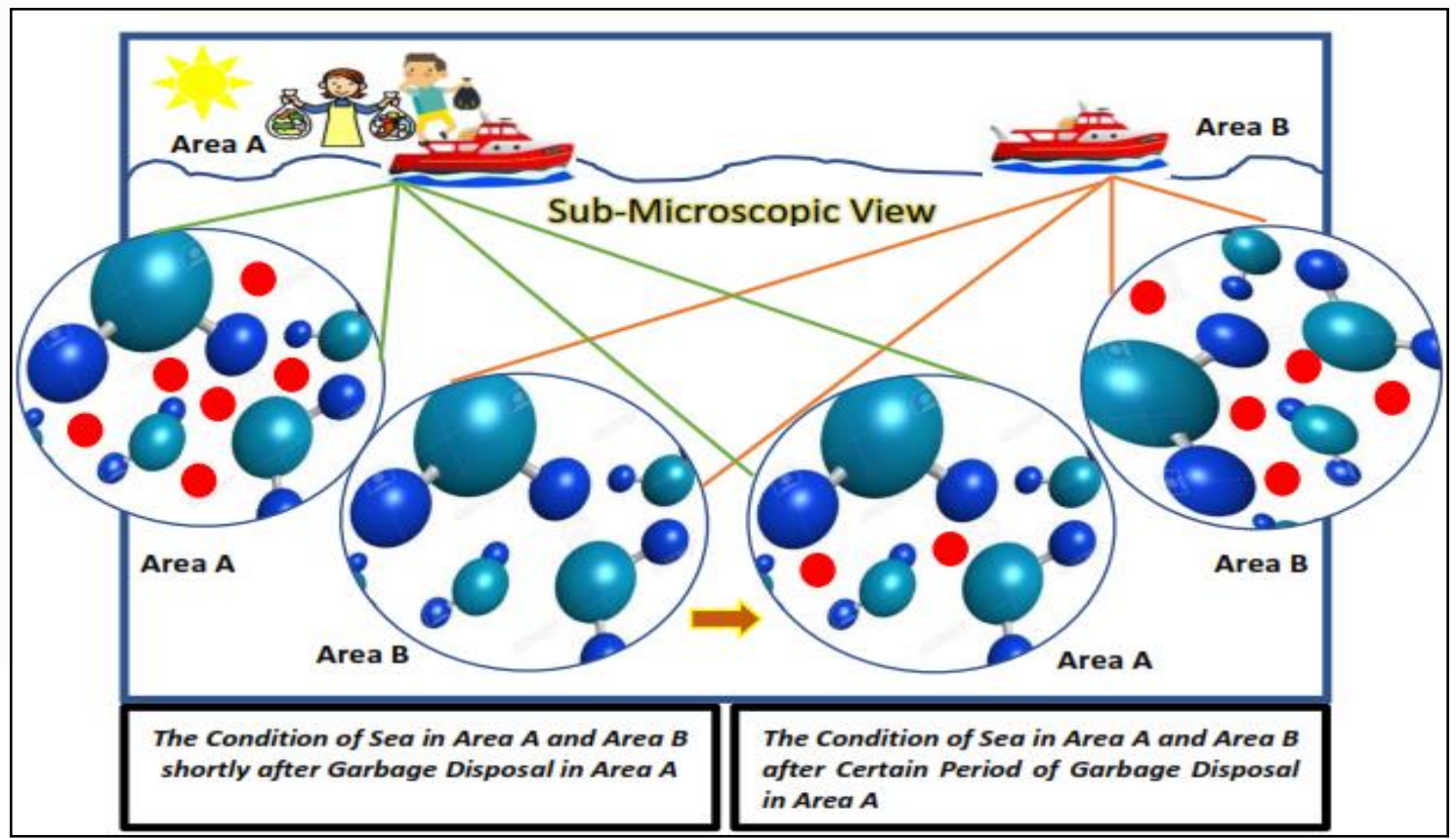

Figure 2. Sea pollutant migration

Students' conceptions about pollution become increasingly complex as they get older, and teachers are challenged to choose learning strategies and evaluations that are appropriate to the context and development of students' cognitive dimensions (Stavridou \& Marinopoulos, 2001). Student conceptions about pollution problems are abstract and difficult to measure, therefore, teachers need to consider the stages of cognitive development and the ages of their students when developing activities to promote student understanding about pollution in order to avoid misconceptions (Valeiras \& Godoy, 2007). Research shows that student understanding about the concept of the 
environment is incomplete, and they are unable to show the connection between fundamental concepts of environmental knowledge (Liu \& Lin, 2015; Rebolj \& Devetak, 2013). Students tend to separate the objects of observation rather than understanding the relationship between such objects and the processes which occur in nature (Ahi, Balci, \& Alisinanoğlu, 2017; Liu \& Lin, 2015). Even teachers experience misconceptions about environmental issues (Liu, Yeh, Liang, Fang, \& Tsai, 2015). The results from another also shows that misconceptions about environmental problems, especially pollution in water areas, are relatively high amongst primary students (Stavridou \& Marinopoulos, 2001).

The teacher should teach the concept of the environment correctly to students. However, research findings show that many teachers have misconceptions about environmental issues (Aksan \& Çelikler, 2015; Boo, 2005; Çelikler \& Aksan, 2014; Chaniarosi, 2014; Lukmanudin, 2017); the findings also show that teachers are the main source of creating misconceptions in student understanding because a teacher is the single source of learning in the classroom. Therefore, teachers need to master the basic concepts of science to support a learning activity, and to minimize the likelihood of misconceptions occurring in student understanding. Accurate measuring instruments are needed to ensure the mastery level of teachers occurs about the basic concepts of science and environment, especially regarding pollutant migration into the sea.

Conceptions and misconceptions cannot be measured by ordinary questions about the definition, evidence, and resolution of standard problems (KaltakciGurel, Eryilmaz, \& McDermott, 2017; McDermott, 1991). Factually several studies show ways in which to measure teacher misconceptions about various concepts, for example through standardized multiple-choice (Etobro \& Banjoko, 2017), Certainty Response Index (Syahdan, 2017), and three-tier diagnostic tests (Arslan, Cigdemoglu, \& Moseley, 2012). Based on our analysis, these tests have not measured conceptions at the sub-microscopic level in the form of visualizations or images.

Visual representations can be an alternative way to investigate conceptions and misconceptions because teachers and students tend to use figures and texts to explain multi-representations of abstract phenomena (Nurmalasari, 2016; Sopandi, Kadarohman, Rosbiono, Latip, \& Sukardi, 2018). For example, drawing is a mechanism that can capture representations of conceptions and misconceptions as well as show developments in cognitive thinking (Einarsdottir, Dockett, \& Perry, 2009; Haney, Russell, \& Bebell, 2004). Drawing is also a reflection of the way of thinking (Pridmore \& Bendelow, 1995). Drawing activities are also a construction activity that combines hands-on and minds-on activities as well as visualizing and interpreting the data possessed (Ainsworth, Prain, \& Tytler, 2011; Glynn \& Muth, 2008; Quillin \& Thomas, 2015; Schwarz et al., 2009). Drawing is an alternative way to show the representation of conceptions and misconceptions as a whole, and it also enables a complementary verbal ability of interpreting the drawing to occur. Other assessment techniques don't always allow for the visualization of conceptual understanding to be demonstrated (Bahar, Ozel, Prokop, \& Usak, 2008). Therefore, a measurement instrument that is capable of investigating conceptions holistically is needed. The understanding of pre-service primary school teachers about the migration of pollutants into the sea will be 
measured by paying attention to the multiple representations shown by figures, such as drawing, and by complementary verbal explanations.

A diagnostic four-tier question that includes an illustrative figure will be a suitable instrument to investigate the understanding pre-service primary school teachers have about the migration of pollutants into the sea. Conventional fourtier questions usually contain multiple-choice questions about a concept, the level of confidence in answering the previous question, a reason, and a level of confidence for the given reason (Kaltakci-Gurel, Eryilmaz, \& McDermott, 2015; Kaltakci-Gurel, Eryilmaz, \& McDermott, 2017). Such a framework is modified for this study by adding instructions to participants for them to create a figure or drawing from which they can clarify the previously given answers and/or written responses. The level of confidence is only asked at the end of the instrument because the student's answers must be integrated and continuous. The content in focus are sea currents and the migration of pollutants into the sea.

In Indonesia, convection material is taught to students in primary and high school. Students are also repeatedly taught from primary to secondary years of schooling that marine pollution is caused by the release of garbage and/or oil spills into the sea. However, sea currents are rarely introduced by the teacher as an example of a contextual convection event which is associated with the migration of pollutants into bodies of water including the sea. The seawater convection process is a cause of pollutant migration. Discussions about convection and marine pollution are repeated until secondary school, but integrative discussion about how the two areas of content are connected are not carried out very much. If such discussion occurs in class, the presentation of material is only limited to textbooks and expository narratives. The teaching of convection and marine pollution in an integrated manner is very important because it is not only contextual, it is also a socio-scientific issue.

Based on the preceding description, this article seeks to answer the following research question: "How do conceptions held by pre-service primary school teachers about sea currents and migration of pollutants into the sea become represented through use of a four-tier diagnostic test, and is there a correlation between those conceptions?" Therefore, this study aims to investigate the understanding of pre-service primary school teachers about sea currents and the migration of sea pollutants by using four-tier diagnostic tests. The study also aims to investigate how the basic concepts of science about sea currents can influence the conceptions held by pre-service primary school teachers about the migration of sea pollutants.

\section{Methodology}

\section{Research Design and Subject}

This research was a quantitative descriptive study with 147 pre-service primary school teachers completing their 6th semester at one of the teacher training institutions in Indonesia. The participants had already taken some classes about fundamental science and pedagogy. This study was a descriptive case that explained a phenomenon with numbers to access the characteristics of individuals or groups (Bernard \& Bernard, 2013; Creswell \& Creswell, 2017; Punch, 2013). Purposive sampling occurred because the study intended to investigate 
the conceptions held by pre-service primary school teachers who took an interest in the field of science. Furthermore, purposive sampling techniques helped to avoid research bias towards a particular object (Fraenkel, Wallen, \& Hyun, 2011). The research process was completed by choosing purposive subjects then collecting data and then processing the data.

\section{Data Collection Instrument and Process}

This study used a modified four-tier diagnostic question instrument (KaltakciGurel, Eryilmaz, \& McDermott, 2017). This instrument consists of two problems: one problem is related to sea currents, and the other problem is related to sea pollutant migration. Each problem contains four questions. The first question is about the nature of sea currents and pollutant migration. The second question focuses on participant explanations or reasons for their verbal answers. The third question covers visual explanations to show representations of science. The fourth question is about participant beliefs in answering the questions. Three experts from chemistry education, integrated science education, and basic education were involved in a validation process of the instrument to check for accuracy and coherency. The instrument also includes unstructured interviews to get clearer and more detailed answers from the participants.

The conceptions of pre-service primary school teachers about sea currents and migration of sea pollutants were analyzed, categorized, and rated according to the answers written on the answer sheet as shown below in Table 1.

Table 1

Combination Answers and Decisions in the Four-Tiers

\begin{tabular}{|c|c|c|c|c|c|}
\hline \multirow{2}{*}{ Decision } & \multicolumn{4}{|c|}{ Answer Combination } & \multirow{2}{*}{ Score } \\
\hline & $1^{\text {st }}$ tier & $2^{\text {nd }}$ tier & $3^{\text {rd }}$ tier & $4^{\text {th }}$ tier & \\
\hline $\begin{array}{l}\text { Scientific } \\
\text { Conception }\end{array}$ & Know / Correct & Correct & $\begin{array}{l}\text { Connected } \\
\text { Sub- } \\
\text { Microscopic }\end{array}$ & Sure & 2 \\
\hline \multirow{2}{*}{$\begin{array}{l}\text { Lack of Knowledge } \\
1\end{array}$} & Know / Correct & Correct & Connected & Sure & \multirow{2}{*}{2} \\
\hline & Know / Correct & Correct & Unconnected & Sure & \\
\hline \multirow{2}{*}{$\begin{array}{l}\text { Lack of Knowledge } \\
2\end{array}$} & Know / Correct & Correct & Unconnected & Not Sure & \multirow[b]{2}{*}{1} \\
\hline & Know / Correct & $\begin{array}{l}\text { Partly } \\
\text { Correct }\end{array}$ & Connected & Sure & \\
\hline \multirow{2}{*}{ Misconception } & Know / Correct & Incorrect & Connected & Sure & \multirow{2}{*}{0} \\
\hline & Know / Correct & Incorrect & Unconnected & Sure & \\
\hline \multirow{7}{*}{$\begin{array}{l}\text { Have } \\
\text { Conception }\end{array}$} & Know / Correct & Incorrect & Unconnected & Not Sure & \multirow{7}{*}{0} \\
\hline & Know / Correct & Incorrect & $\begin{array}{l}\text { Unconnected, } \\
\text { abstract }\end{array}$ & Sure & \\
\hline & Know / Correct & Incorrect & $\begin{array}{l}\text { Unconnected, } \\
\text { abstract }\end{array}$ & Not Sure & \\
\hline & $\begin{array}{l}\text { Doesn't know / } \\
\text { Incorrect }\end{array}$ & Incorrect & Unconnected & Sure & \\
\hline & $\begin{array}{l}\text { Doesn't know / } \\
\text { Incorrect }\end{array}$ & Incorrect & Connected & Sure & \\
\hline & $\begin{array}{l}\text { Doesn't know / } \\
\text { Incorrect }\end{array}$ & Incorrect & Unconnected & Sure & \\
\hline & $\begin{array}{l}\text { Doesn't know / } \\
\text { Incorrect }\end{array}$ & Incorrect & Unconnected & Sure & \\
\hline
\end{tabular}


Sopandi, W.: Sukardi, R., R. (2020). Using Four-Tier Diagnostic Test to Understand the ...

\begin{tabular}{|c|c|c|c|c|c|}
\hline \multirow{4}{*}{ Decision } & \multicolumn{4}{|c|}{ Answer Combination } & \multirow{4}{*}{ Score } \\
\hline & $1^{\text {st }}$ tier & $2^{\text {nd }}$ tier & $3^{\text {rd }}$ tier & $4^{\text {th }}$ tier & \\
\hline & $\begin{array}{l}\text { Doesn't know / } \\
\text { Incorrect }\end{array}$ & Incorrect & Unconnected & Not Sure & \\
\hline & $\begin{array}{l}\text { Doesn't know / } \\
\text { Incorrect }\end{array}$ & Incorrect & Unconnected & Sure & \\
\hline
\end{tabular}

To investigate the understanding pre-service primary teachers have about sea currents and sea pollutant migration, the test results are examined in accordance with Table 1. The results were then presented descriptively in the form of tables to find out (i) the percentage of pre-service primary teachers who know both the concept of sea currents and sea pollutant migration; and (ii) the quality of verbal and visually represented answers together with their beliefs about answering the question. The data is also calculated to find out the average value, standard deviation, and normality. An understanding about the relationship made by participants between their knowledge about sea currents and about sea pollutant migration is obtained through a Kolmogorov-Smirnov normality test and Spearman's non-parametric correlation test.

\section{Findings}

The results of this research are presented in three main points: the conceptions held by pre-service primary teachers about sea currents; the conceptions held by pre-service primary school teachers about the sea pollutant migration; and the correlations identified between the two conceptions. The conceptions of pre-service primary teachers about sea currents are presented below in Table 2.

Table 2

Pre-Service Primary Teachers' Conceptions about Sea Currents

\begin{tabular}{|c|c|c|c|c|c|}
\hline No. & Aspects & Percentages (\%) & & & \\
\hline 1 & $\begin{array}{l}\text { Sea current } \\
\text { Conception }\end{array}$ & Knows Conception: $98^{\circ}$ & Doesn't Knou & onception: $2 \%$ & \\
\hline 2 & Verbal Explanation & Correct $2 \%$ & Partly Correct $2 \%$ & Incorrect 95\% & \\
\hline 3 & Visual Explanation & $\begin{array}{l}\text { Connected Sub- } \\
\text { Microscopic: } 0.68 \%\end{array}$ & $\begin{array}{l}\text { Connected- } \\
\text { Macroscopic: } \\
99.32 \%\end{array}$ & $\begin{array}{l}\text { Unconnected } \\
\text { error: } 0 \%\end{array}$ & and \\
\hline 4 & Answers Belief & Sure: $84 \%$ & Not Sure: & & \\
\hline
\end{tabular}

As seen in Table 2, almost all of the pre-service primary school teachers know about sea currents (98\%). Unfortunately, their verbal and visual explanations show their conceptions to be at a very low level. Only a small percentage of participants can provide scientific explanations, both verbally $(2 \%)$ and visually (0.68). The large percentage score about participant beliefs in their answers provided to the previous three questions (84\%) indicates they are not guessing a response to the questions but are instead putting forward their firmly held beliefs.

The conceptions held by pre-service primary school teachers about sea pollutant migration are presented below in Table 3. Pre-service primary school teacher participants claim to recognize the migration of sea pollutants (76\%), however, their ability to explain both verbally and visually remains low and only a small percentage of the group can explain scientific phenomena both verbally $(0.68 \%)$ and visually $(0.68 \%)$. Again, as with the findings from Table 2 , the large percentage score about participant beliefs in their answers (84\%) suggests 
figures in the test is also able to show a deeper understanding about participant representations. Anderson, Ellis, \& Jones (2014); Sopandi, Kadarohman, Rosbiono, Latip, \& Sukardi (2018) also corroborate to say that figures can show submicroscopic representations and represent verbal explanations. Figure 3 and Figure 4 are examples of a comparison between student answers in the 3rd tier which have the same answer as in the 1st tier.

Figure 3 and Figure 4 show the drawings from pre-service primary teachers about the migration of sub-microscopic and macroscopic pollutants. The drawings occur in response to the 3rd tier of questions in the diagnostic test. Investigating sub-microscopic figures is very important in science learning. This is because sub-microscopic drawing is a characteristic of science (Ainsworth, Prain, \& Tytler, 2011; Chittleborough \& Treagust, 2007; Quillin \& Thomas, 2015; Schwarz et al., 2009).

Convection of seawater which is a scientific concept about sea currents cannot be explained in Figure 3 . Figure 3 only shows the macroscopic representation of how water moves due to sea currents. Figure 4 shows an understanding from participants that sea currents occur because of differences in temperature in a body of water. The temperature difference between two bodies of water causes warmer water to move to cooler waters. Dissolved pollutants will move along with sea current (Smith, 2004; Soloviev \& Klinger, 2001).

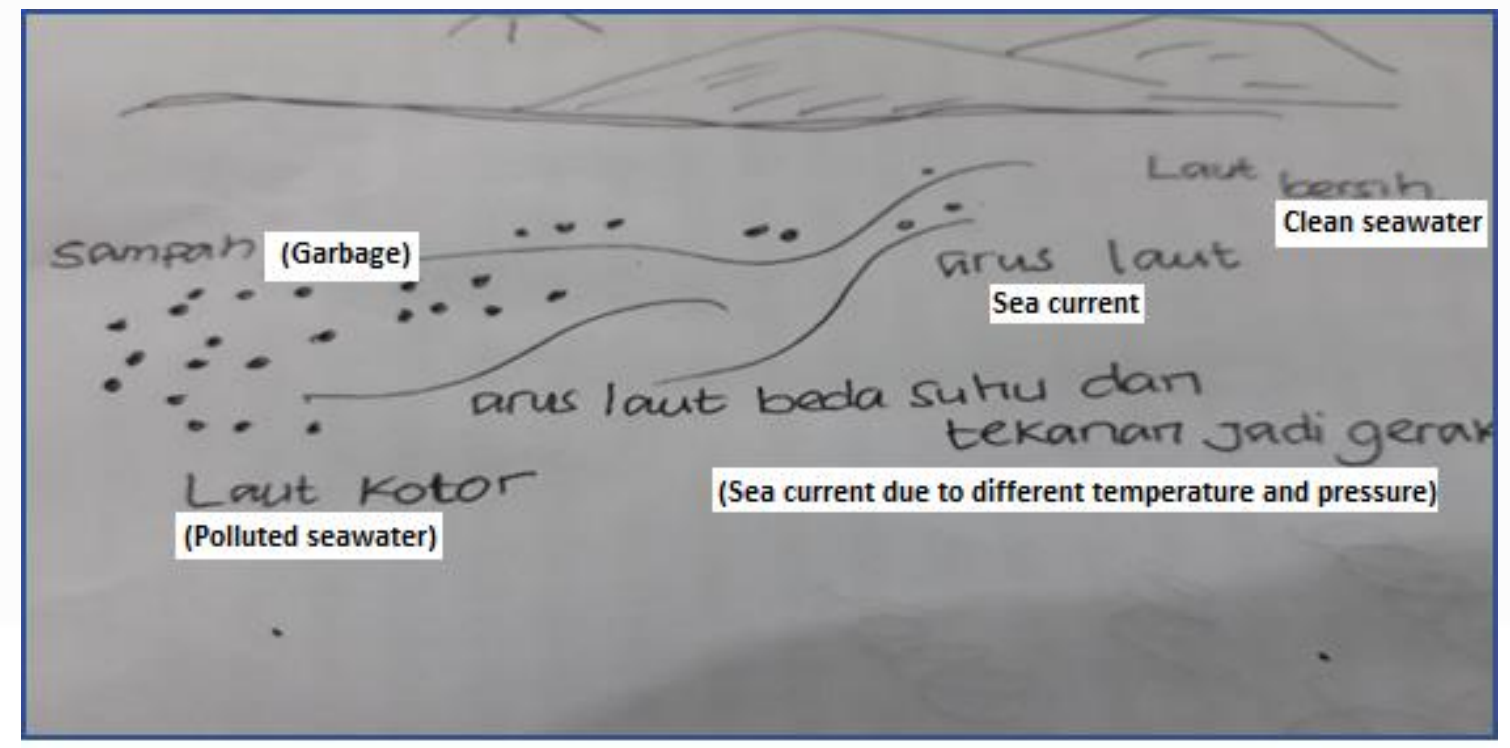

Figure 3. Pre-service primary school teacher's sub-microscopic drawing 


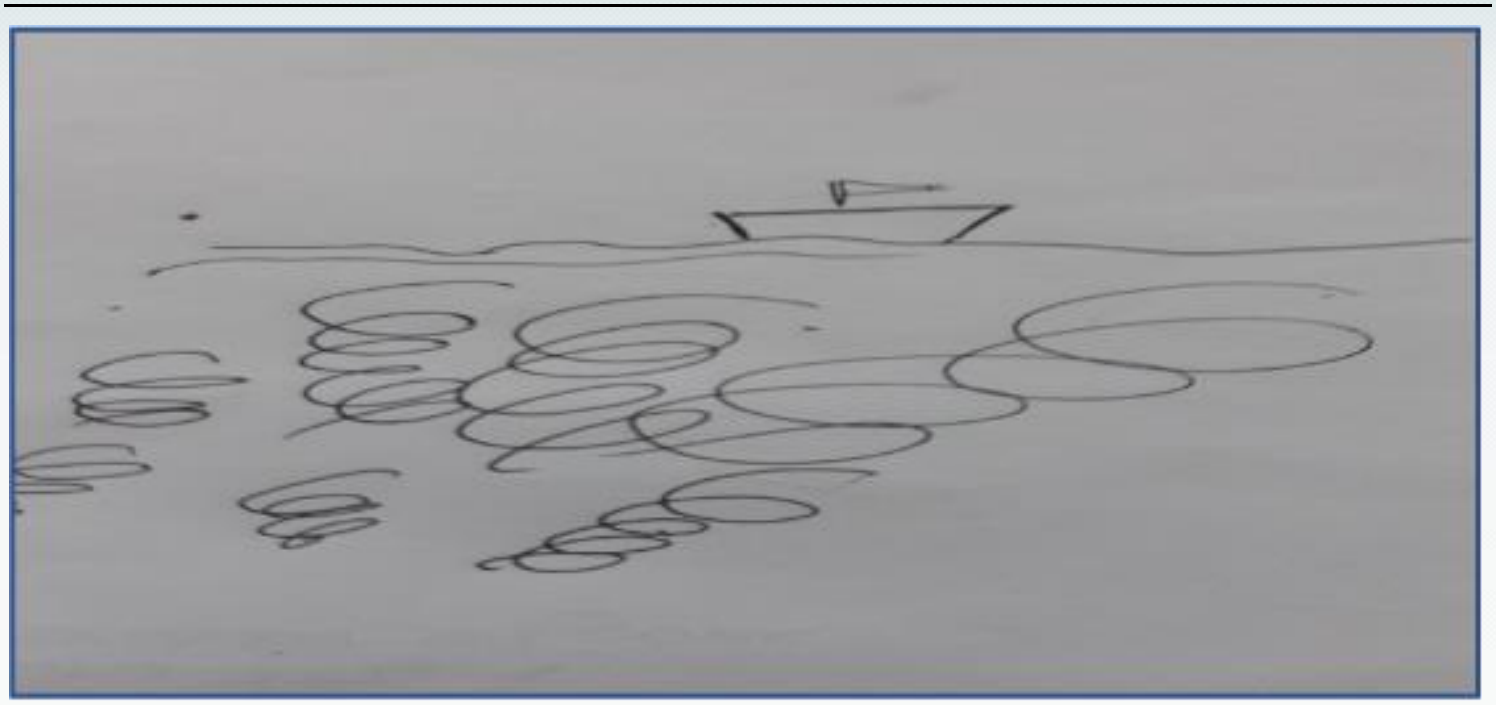

Figure 4. Pre-service primary school teacher's macroscopic drawing

Many categories of 'misconceptions' or 'have no conceptions' are also caused by misunderstanding (Prodjosantoso, Hertina, \& Irwanto, 2019). Some of the participants in the current study stated that pollutants and seawater would not coalesce because the sea has a certain limit that cannot be penetrated. After all, it has a strong attractive force on the molecule. According to some of the participants, the volume of water is far greater than that of pollutants so the pollutants will not spread far from the source. There are even some pre-service primary school teachers who claim that pollutants in seawater will evaporate into clouds, and these clouds will produce rain which is full of pollutants as well. This finding indicates that the learning of convection or sea currents carried out by the teacher only emphasizes the process of remembering facts. Therefore, students in classrooms who are learning from the teacher will certainly experience difficulties in correctly understanding sea currents and sea pollutant migration when faced with contextual problems such as teachers sharing information learned through a rote learning process.

\section{The Correlation of Pre-Service Primary School Teachers' Conceptions about Sea Currents and Sea Pollutant Migration}

A teacher was a student in the past who also learned from a teacher. Therefore, pre-service teachers must have correct knowledge rather than misconceptions so they can convey factual and contextual knowledge correctly to their students (Hussein, 2018; Liu, Yeh, Liang, Fang, \& Tsai, 2015). To provide integrated and appropriate knowledge to students, a subject-centered, contextual, authentic, and continuous learning approach is needed (Radcliffe, Parissi, \& Raman, 2016). This is because the purpose of science learning is to develop knowledge and understanding about the environment in a sustainable manner (Rooy, 2017). However, results from the correlation analysis between the conceptions held by pre-service primary school teachers about sea currents and the migration of pollutants also showed an insignificant relationship although the two concepts were closely related. Such a finding about low correlation occurring between concepts among pre-service teachers is confirmed by the results of a study which states that pre-service teachers of Physics and Biology have difficulty connecting the concepts to build a contextual explanation of 
complex phenomena such as sea pollution (Meilinda, Rustaman, Firman, \& Tjasyono, 2017). Pre-service primary school teachers have a diverse understanding of the basic concepts of science because not all of them have studied in the science department at high school. To be able to answer the questions in the current study, pre-service primary school teachers should have a good understanding about the concept of convection in order to explain sea currents and the migration of sea pollutants. The findings of further research show there is no significant difference between pre-service primary school teachers with different majors in high school. They all failed to understand the relationship between convection, sea currents, and migration of sea pollutants. It is likely to be because the three phenomena are not systematically delivered. Besides, the learning model or method used so far does not facilitate thinking to occur amongst students, only for students to remember scientific facts or a basic concept or law of science. Science learning aims to make students not only able to understand contextual problems macroscopically but also submicroscopically. Therefore, conceptual capabilities about the environment must be built continuously from primary to secondary school levels and even in university about the environment, including in teacher education courses.

\section{Sustainable Learning Process}

Students learn about convection from primary school to secondary school. But the contextual example given in books and by teachers is only the process of boiling water, even though sea currents are a typical example and are key to the process of spreading pollutants in the sea. This phenomenon is not a sustainable teaching concept but a stagnation that misleads students' cognitive development. Furthermore, most of the students think that everything that comes from nature is not a pollutant because the theme of pollution is only partially taught throughout primary and secondary education (Stavridou \& Marinopoulos, 2001). Students should be introduced to contextual issues, be involved in discussion and the investigation of phenomena, or be conducting inquiry activities which result in a longer retention of knowledge (Tolppanen \& Aksela, 2018; Williams, McEwen, \& Quinn, 2017). The results of unstructured interviews with pre-service students show they were rarely involved in science process activities. The lack of field experience and the opportunity for students to discover and observe the environment compared to recording scientific facts in the classroom will limit the potential of students to identify the science process in the basic education order (Tugurian \& Carrier, 2017). By involving various sensory functions and direct experience in science-focused learning, primary students are able to better connect their understanding about nature, physics, and social aspects (Meng \& Trudel, 2017; Murakami, Su-Russell, \& Manfra, 2018). A more advanced step is to introduce multi representational learning at the high school or college level. Continuing education about the environment is one solution for students in solving contextual problems as well as standardized tests such as state examinations (Warner \& Elser, 2015).

The curriculum plays an important role in supporting the development of students' factual knowledge competencies so that students can understand contextual problems (Mahasneh, Romanowski, \& Dajani, 2017; Sammel, McMartin, \& Arbuthnott, 2018). Teaching environmental concepts such as the mechanism of dispersing pollutants requires a continuous curriculum. Payne 
(2016), revealed that basic education is strongly influenced by the paradigm and orientation of the curriculum which is based on sustainability. In the order of secondary school education, teachers should communicate environmental issues to get solutions in a positive and futuristic way (Ojala, 2015). Nazir (2016), revealed that optimizing the senses can help students to see conceptualization and training in environmental education in the context of study in class. If all the above conditions have been fulfilled, it will be easy to teach sub-microscopic representations at the next educational level. Teaching sub-microscopic representation collaborated with contextual problems through audio-visual media will appeal to high school students (Bahk, 2010; Bosschaart, Schee, \& Kuiper, 2016).

\section{Conclusions \& Suggestions}

\section{Conclusions}

This study reveals the conceptual understandings held by pre-service primary school teachers about the process of sea currents and sea pollutant migration. By using the four-tier diagnostic test tool, it was revealed that the conceptual understanding of the pre-service primary school teacher in both topics was still low. This might happen because learning the fundamental concept of convection in connection with the occurrence of sea currents has not been associated with phenomena in daily life. This shows the importance of learning needed to start from the phenomena of daily life. The research results about the absence of a relationship between the two variables indicate that even if the concept of sea currents is mastered, it does not mean the concept of pollutant migration into the sea will also be mastered, and vice versa.

\section{Suggestions}

All the findings resulting from the current study indicate the need for an explicit explanation from teachers to occur about the relationship between the concepts of convection, sea currents, and pollutant migration into the sea. Additionally, the learning objectives when delivering sea current material to students must be sustainable at every level of the school to be able to build a complete understanding of science, including through the use of multiple representations.

This study merely seeks to describe the conceptions held by pre-service primary school teachers about their conceptions of the two topics studied. Further research is needed about improving the conceptual understanding of the pre-service primary school teachers about the two phenomena of this study. With a good conceptual understanding about convection, sea currents, and sea pollution migration, teachers can prepare students to become citizens who can contribute to the creation of a free pollutant aquatic environment. 
Sopandi, W.: Sukardi, R., R. (2020). Using Four-Tier Diagnostic Test to Understand the ...

\section{References}

Ahi, B., Balci, S., \& Alisinanoğlu, F. (2017). Exploring Turkish preservice teachers' mental models of the environment: Are they related to gender and academic level? The Journal of Environmental Education, 48(3), 182-195.

Ainsworth, S., Prain, V., \& Tytler, R. (2011). Drawing to learn in Science. Science, 333(6046), 1096-1097.

Aksan, Z., \& Çelikler, D. (2015). Evaluation of the knowledge and misconceptions of Science teacher candidates in Turkey regarding the greenhouse effect through the use of drawings. Journal of Education and Practice, 6(13), 112-120.

Anderson, J. L., Ellis, J. P., \& Jones, A. M. (2014). Understanding early elementary children's conceptual knowledge of plant structure and function through drawings. CBELife Sciences Education, 13(3), 375-386.

Arslan, H. O., Cigdemoglu, C., \& Moseley, C. (2012). A three-tier diagnostic test to assess pre-service teachers' misconceptions about global warming, greenhouse effect, ozone layer depletion, and acid rain. International Journal of Science Education, $34(11), 1667-1686$.

Bahar, M., Ozel, M., Prokop, P., \& Usak, M. (2008). Science student teachers'ideas of the heart. Journal of Baltic Science Education, 7(2), 78-85.

Bahk, C. M. (2010). Environmental education through narrative films: Impact of medicine man on attitudes toward forest preservation. The Journal of Environmental Education, 42(1), 1-13.

Bernard, H. R., \& Bernard, H. R. (2013). Social research methods: Qualitative and quantitative approaches. Singapore: Sage Publications, Inc.

Bolscho, D., \& Havenschild, K. (2006). From environmental education to education for sustainable development in Germany. Environmental Education Research, 12(1), 7-18.

Boo, H. K. (2005, November). Teachers' misconceptions of biological science concepts as revealed in science examination papers. Retrieved from https://repository.nie.edu.sg//handle/10497/4403

Bosschaart, A., Schee, J.V.D., \& Kuiper, W. (2016). Designing a flood-risk education program in the Netherlands. The Journal of Environmental Education, 47(4), 271286.

Çelikler, D., \& Aksan, Z. (2014). Determination of knowledge and misconceptions of preservice elementary Science teachers about the greenhouse effect by drawing. Procedia - Social and Behavioral Sciences, 136, 452-456.

Chaniarosi, L. F. (2014). Identifikasi miskonsepsi guru Biologi SMA kelas XI IPA pada konsep sistem reproduksi manusia. Jurnal Edubio Tropika, 2(2), 187-250.

Chittleborough, G., \& Treagust, D.F. (2007). The modelling ability of non-major Chemistry students and their understanding of the sub-microscopic level. Chemistry Education Research and Practice, 8(3), 274-292.

Creswell, J. W., \& Creswell, J. D. (2017). Research design: Qualitative, quantitative, and mixed methods approaches. Singapore: Sage publications.

Einarsdottir, J., Dockett, S., \& Perry, B. (2009). Making meaning: Children's perspectives expressed through drawings. Early Child Development and Care, 179(2), 217-232.

Etobro, A. B., \& Banjoko, S. O. (2017). Misconceptions of genetics concepts among preservice teachers. Global Journal of Educational Research, 16(2), 121-128. 
European Commission's Directorate-General Environment. (2011). In-Depth Report Plastic Waste: Ecological and Human Health Impact. University of the West of England. (Bristol).

Fraenkel, J. R., Wallen, N. E., \& Hyun, H. H. (2011). How to design and evaluate research in education. New York: McGraw-Hill Humanities/Social Sciences/Languages.

Glynn, S., \& Muth, K. D. (2008). Using drawing strategically. Science and Children, 45(9), $48-51$.

Haney, W., Russell, M., \& Bebell, D. (2004). Drawing on education: Using drawings to document schooling and support change. Harvard Educational Review, 74(3), 241-272.

Hussein, H. (2018). A critique of water scarcity discourses in educational policy and textbooks in Jordan. The Journal of Environmental Education, 49(3), 260-271.

Informasi Kinerja Pengelolaan Lingkungan Hidup Daerah Provinsi Jawa Timur. (2017). Laporan Utama. Environmental Agency of East Java Province. (Surabaya).

Kaltakci-Gurel, D., Eryilmaz, A., \& McDermott, L. C. (2015). A review and comparison of diagnostic instruments to identify students' misconceptions in science. Eurasia Journal of Mathematics, Science and Technology Education, 11 (5), 989-1008.

Kaltakci-Gurel, D., Eryilmaz, A., \& McDermott, L. C. (2017). Development and application of a four-tier test to assess pre-service physics teachers' misconceptions about geometrical optics. Research in Science \& Technological Education, 35(2), 238260.

Kasimov, N., Malkhazova, S., \& Romanova, E. (2002). The role of environmental education for sustainable development in Russian Universities. Planet, 8(1), 24-25.

Kurniawan, B. (2013). Water pollution control in Indonesia. Retrieved from http://wepadb.net/activities/2014/20141127/pdf/1_4_WEPA-THAILAND-BUDI.pdf

Liu, S.-C., \& Lin, H. (2015). Exploring undergraduate students' mental models of the environment: Are they related to environmental affect and behavior? The Journal of Environmental Education, 46 (1), 23-40.

Liu, S.-Y., Yeh, S.-C., Liang, S.-W., Fang, W.-T., \& Tsai, H.-M. (2015). A national investigation of teachers' environmental literacy as a reference for promoting environmental education in Taiwan. The Journal of Environmental Education, 46(2), 114-132.

Lukmanudin. (2017). Penguasaan konsep IPA dan kemampuan menjelaskan fenomena perpindahan zat pencemar melalui pembelajaran RADEC. (Masters, Universitas Pendidikan Indonesia). Retrieved from http://repository.upi.edu

Mahasneh, R. A., Romanowski, M. H., \& Dajani, R. B. (2017). Reading social stories in the community: A promising intervention for promoting children's environmental knowledge and behavior in Jordan. The Journal of Environmental Education, 48(5), 334-346.

Martinus, Y., Astono, W., \& Hendrawan, D. (2018). Water quality study of Sunter River in Jakarta, Indonesia. IOP Conference Series: Earth and Environmental Science, 106, 012022. https://doi.org/10.1088/1755-1315/106/1/012022

McDermott, L. C. (1991). Millikan Lecture 1990: What we teach and what is learnedClosing the gap. American Journal of Physics, 59(4), 301-315.

Meilinda, M., Rustaman, N., Firman, H., \& Tjasyono, B. (2017). Development climate changes lecturer in Earth Science and Space Course and Environmental Course for pre-service Science teachers: 2nd Asian Education Symposium, 161-166. https://doi.org/10.5220/0007300401610166 
Sopandi, W.: Sukardi, R., R. (2020). Using Four-Tier Diagnostic Test to Understand the ...

Meng, M. D., \& Trudel, R. (2017). Using emoticons to encourage students to recycle. The Journal of Environmental Education, 48(3), 196-204.

Murakami, C. D., Su-Russell, C., \& Manfra, L. (2018). Analyzing teacher narratives in early childhood garden-based education. The Journal of Environmental Education, 49(1), 18-29.

Nazir, J. (2016). Using phenomenology to conduct environmental education research: Experience and issues. The Journal of Environmental Education, 47(3), 179-190.

Nurmalasari, R. (2016). Analisis representasi siswa SMP pada tema kalor dalam perubahan wujud zat (Masters, Universitas Pendidikan Indonesia). Retrieved from http://repository.upi.edu

Ojala, M. (2015). Hope in the face of climate change: Associations with environmental engagement and student perceptions of teachers' emotion communication style and future orientation. The Journal of Environmental Education, 46(3), 133-148.

Payne, P. G. (2016). The politics of environmental education. Critical inquiry and education for sustainable development. The Journal of Environmental Education, 47(2), 69-76.

Pridmore, P., \& Bendelow, G. (1995). Images of health: Exploring beliefs of children using the 'draw-and-write' technique. Health Education Journal, 54 (4), 473-488.

Prodjosantoso, A. K., Hertina, A. M., \& Irwanto. (2019). The misconception diagnosis on ionic and covalent bonds concepts with three tier diagnostic test. International Journal of Instruction, 12(1), 1477-1488.

Punch, K. F. (2013). Introduction to Social Research: Quantitative and Qualitative Approaches. Singapore: SAGE.

Purba, N. P. (2017, October). Sampah dan solusi untuk kesehatan laut. Youth Marine Debris Summit, Jakarta, 24th -29 th 2017 . https://doi.org/10.13140/RG.2.2.32905.34406

Quillin, K., \& Thomas, S. (2015). Drawing-to-learn: A framework for using drawings to promote model-based reasoning in Biology. CBE-Life Sciences Education, 14(1), $1-16$.

Radcliffe, C., Parissi, C., \& Raman, A. (2016). Valuing indigenous knowledge in the Highlands of Papua New Guinea: A model for Agricultural and Environmental Education. Australian Journal of Environmental Education, 32 (3), 243-259.

Rebolj, N., \& Devetak, I. (2013). 15 and 16 years-old students' understanding of factors that influence water pollution. Energy and Environment Research, 3(1), 106-114.

Rooy, W. V. (2017). Early preservice teachers' experiences of the environment: A case study of participation in a community outdoor event. Australian Journal of Environmental Education, 33(2), 81-96.

Sammel, A., McMartin, D., \& Arbuthnott, K. (2018). Education agendas and resistance with the teaching and learning of freshwater and extreme freshwater events. Australian Journal of Environmental Education, 34 (1), 18-32.

Schwarz, C. V., Reiser, B. J., Davis, E. A., Kenyon, L., Achér, A., Fortus, D., . . Krajcik, J. (2009). Developing a learning progression for scientific modeling: Making scientific modeling accessible and meaningful for learners. Journal of Research in Science Teaching, 46(6), 632-654.

Smith, J. A. (2004). Reflecting on the development of interpretative phenomenological analysis and its contribution to qualitative research in psychology. Qualitative Research in Psychology, 1 (1), 39-54. 
Soloviev, A., \& Klinger, B. (2001). Open ocean convection. In Encyclopedia of Ocean Sciences (pp. 2015-2022). https://doi.org/10.1006/rwos.2001.0118

Sopandi, W., Kadarohman, A., Rosbiono, M., Latip, A., \& Sukardi, R. R. (2018). The courseware of discontinuous nature of matter in teaching the states of matter and their changes. International Journal of Instruction, 11 (1), 61-76.

Stavridou, H., \& Marinopoulos, D. (2001). Water and air pollution: Primary students' conceptions about "itineraries" and interactions of substances. Chemistry Education Research and Practice, 2(1), 31-41.

Sukardi, R. R., Widarti, H. R., \& Nurlela, L. (2017). Primary School Students' Submicroscopic Representation Level on Greenhouse Effect at Urban Educational Area: 2nd Asian Education Symposium, 178-183. https://doi.org/10.5220/0007300701780183

Surata, S. P. K., \& Vipriyanti, N. U. (2018). The subak cultural landscape as environmental education: Knowledge, attitudes, and experiences of Balinese teachers, student teachers, and students. The Journal of Environmental Education, 49(1), 59-70.

Syahdan, U. A. (2017). Identifikasi miskonsepsi guru Biologi di Kota Makassar pada konsep Sel dengan menggunakan metode CRI (Certanity Respon Index (Masters, Pascasarjana Universitas Negeri Makasar). Retrieved from http://eprints.unm.ac.id/4391/

Synthesis Report of the Ministry of Maritime Affairs. (2018). Kajian Cepat Laporan Sintesis: Hotspot Sampah Laut Indonesia. Ministry Coordinator of Maritime Affairs in Collaboration with World Bank Group, Embassy of Denmark, and Royal Norwegian Embassy. (Jakarta).

Tolppanen, S., \& Aksela, M. (2018). Identifying and addressing students' questions on climate change. The Journal of Environmental Education, 49(5), 375-389.

Tugurian, L. P., \& Carrier, S. J. (2017). Children's environmental identity and the elementary science classroom. The Journal of Environmental Education, 48(3), 143-153.

Valeiras, N., \& Godoy, L. A. (2007). Understanding environmental pollution concepts: A case study using school students in Argentina and Puerto Rico. International Journal of Environment and Pollution, 31 (3/4), 342-358.

Warner, B. P., \& Elser, M. (2015). How do sustainable schools integrate sustainability education? An assessment of certified sustainable K-12 schools in the United States. The Journal of Environmental Education, 46(1), 1-22.

Williams, S., McEwen, L. J., \& Quinn, N. (2017). As the climate changes: Intergenerational action-based learning in relation to flood education. The Journal of Environmental Education, 48(3), 154-171.

\section{Biographical Statements}

Wahyu SOPANDI is an Associate Professor of Chemistry Education at Universitas Pendidikan Indonesia. He is the holder of a master of art degree (M.A.) from Ohio State University, USA and the holder of a doctorate (Dr.päd) from the University of Münster, Germany. He is the head of Elementary Education Study Program, School of Post Graduate, Universitas Pendidikan Indonesia. His current research is on environmental education subject where he investigates pre-service primary school teachers' conception of seawater pollution and air pollution. His academic interest lies within the broad area of the Read-Answer-Discuss-Explain-and Create (RADEC) learning model, representation of chemistry, and environmental issues.

Rendi Restiana SUKARDI is a lecturer of Elementary Education Study Program in Cibiru Campus, Universitas Pendidikan Indonesia. He got Master of Science education degree 
Sopandi, W.: Sukardi, R., R. (2020). Using Four-Tier Diagnostic Test to Understand the ...

(M.Pd.) from Universitas Pendidikan Indonesia. In 2019, he was accepted as a student of the doctorate of science education program at the same campus. He is the concern with the global warming issue and multi representation on science. His latest publication article was about students' representation of global warming and climate change. Formerly, he was a teacher of environmental studies in a primary school in Bandung, West Java, Indonesia. 